\title{
Research on the Development of Chinese Haute Couture Enterprises from the Perspective of Consumer Demand
}

\author{
Shu Chen, Qiong Long* \\ Business School, Beijing Institute of Fashion Technology, Beijing, China \\ Email: Chenshujocelyn@163.com, *sxylqiong@bift.edu.cn
}

How to cite this paper: Chen, S. and Long, Q. (2019) Research on the Development of Chinese Haute Couture Enterprises from the Perspective of Consumer Demand. Open Journal of Business and Management, 7, 1153-1161.

https://doi.org/10.4236/ojbm.2019.73080

Received: April 1, 2019

Accepted: June 2, 2019

Published: June 5, 2019

Copyright ( 2019 by author(s) and Scientific Research Publishing Inc. This work is licensed under the Creative Commons Attribution International License (CC BY 4.0).

http://creativecommons.org/licenses/by/4.0/

\begin{abstract}
With the development of China's economy and the change of economic structure, consumption has been constantly upgraded, and a large number of middle-class people with high net worth income have emerged. This paper attempts to take LANYU as an example and analyze the development status of China haute couture enterprises with respect to service concept, marketing method and product building of enterprises. It finds the development mode of successful haute couture enterprise and provides feasible suggestions for the development of Chinese advanced customization enterprises.
\end{abstract}

\section{Keywords}

China Haute Couture, Demand of Consumer, Enterprise Development

\section{Introduction}

The concept of "Haute Couture" was originated in France in the 19th century. It refers to the production or processing of clothes beyond the general standard according to customers' needs. It is quoted from the "Haute Couture" of the British tailor Charles Frederick Worth. In the mid-20th century, haute couture reached its peak in France. In the mid-1990s, "haute couture" began to sprout in China. Guo pei, a famous fashion designer, opened the door of the Chinese haute couture market, and then a large number of excellent Chinese haute couture designers emerged. Among them, Lan Yu, the Haute Couture Queen of China, is committed to becoming a person who helps others realize their dreams. In 2005, she founded her own studio. With her unique business philosophy, she has become the most rapidly growing and influential designer of wedding dresses for the post-1985 generation in China. 
Maslow's demand effect divides human needs into five levels: physiological needs, safety needs, social needs, respect needs and self-actualization needs. Nowadays, with the development of social economy and the adjustment of economic structure, the national income level has been greatly improved, and the basic needs of domestic consumers have been fully met, and they are developing towards the demand for respect, self-actualization and other advanced demands.

According to a report released by credit suisse, China's new middle class has reached 109 million by 2016. With the development of economy, consumption upgrading and deepening of Internet, the scale of China's new middle class is expected to rise to 300 million to 500 million between 2020 and 2025. The "new middle class" has gradually become the backbone of China's consumer economy. BCG and Ali research institute jointly released the "China consumption trend report", which showed that by 2020 , the Chinese consumer market will add 2.3 trillion dollars (about 14.9 trillion yuan), among which the middle class and affluent consumers will contribute $81 \%$ of the increase in consumption. Studies predict that by 2027, China's middle class will grow even larger, accounting for 65 percent of all households, thanks to rising per capita income in urban areas. These new middle classes not only have the willingness to consume customized products, but also have enough spending power. Under the dual effect of the Chinese government's reduction of import tariffs and cultural confidence, more and more hnwis choose domestic products with high quality, influence and personality, including haute couture products. However, China's haute couture enterprises are in the stage of development and cultivation, and the market supply is unbalanced. If China's haute couture enterprises want to achieve further development, they still need to think and explore more. This paper attempts to take LANYU company as an analysis case, in order to get inspiration from it, so that China's haute couture enterprises can seize the demand of the consumption upgrade of the new middle class, and achieve better development.

\section{Literature Review}

At present, the development of China's haute couture enterprises has not yet formed a mature system, and enterprises are trying to explore and find a way to adapt to the domestic market and meet the needs of consumers Chinese style high set development path. Domestic scholars have relatively few studies on the relationship between haute couture enterprises and consumers. Most of the existing studies focus on the marketing strategies of haute couture enterprises, the technical application of haute couture products, the deficiencies in enterprise operation and the future development strategies of enterprises.

First, in terms of the marketing strategy of the haute couture enterprise, Zhao Yuan (2015), by summing up the characteristics of custom dress enterprises, according to the characteristics of the "product + services", put forward $4 \mathrm{P}+4 \mathrm{C}$ marketing theory. In her opinion, $4 \mathrm{P}$ and $4 \mathrm{C}$ are the tools and basis of enterprise 
marketing respectively, and they are indispensable. Only by combining them can they "fully adapt to the modern marketing rules oriented by consumer needs" [1]. Chen miaomiao (2016) integrated the lifestyle marketing theory into the men's shirt customization mode, and believed that only by starting from the lifestyle of target consumers and exploring their physiological and psychological needs, can consumption upgrade be better promoted [2]. Liu hua (2018), through the marketing case analysis of Grace Chen and Bouthentique, believes that a high degree of matching between products and consumer demand is a necessary condition for the healthy development of the brand, and a good brand marketing model of women's wear is the key to meet the conditions [3]. At present, the concept of haute couture has penetrated into different types of enterprises, targeting target consumers, accurate positioning of brand categories, styles, prices, etc., so that enterprises can better promote consumption upgrading.

Secondly, in the research on the emotional relationship between haute couture products and consumers, Zhang xia (2017) put the research on the correlation between "love" and "shape" in haute couture clothing, and believed that haute couture design should pay close attention to the emotional expression of consumers, so as to establish the self-image and social status required by consumers. At the same time, we should try to make emotional implantation and body design convenient for consumers and reduce their decision-making time [4]. Chen wenlu (2016) found in the research on VIP customized design management that the consumption consciousness of female VIP customized consumers in the new era has changed and they have their own personalized needs, including emotional design, emotional consumption and shaping aesthetic confidence under the concept of sustainable development [5]. Dong Zhanxun and Li Yanan (2015) integrated emotional design mode into every process from design and production to sales of haute couture garments, and believed that emotional design is an important means to realize the upgrading of China's garment industry [6]. The audience of haute couture products often pay more attention to spiritual consumption. Analyzing the emotional needs of target consumers is the key point of product research and development and design management.

Thirdly, in terms of the technical application of haute couture products, Peng hui (2016) has carried out relevant research on digital intelligent customized clothing, and believes that its intelligent manufacturing technology can meet a number of consumer needs such as personalization, diversification and efficiency, and build a new consumption experience. The perceptive value of digital intelligent clothing customization is defined from seven dimensions [7]. Zhang baolong (2017) introduced C2M, a brand new e-commerce mode directly facing factories, into online garment customization. The introduction of C2M mode will not only meet the personalized needs of consumers, but also reduce inventory pressure, so as to achieve a balance between consumers and enterprises [8]. With the development of digital technology, intelligent manufacturing has also 
been applied to the field of clothing customization to assist the analysis of consumers' individual needs and provide convenience for haute couture enterprises.

In conclusion, most of the researches on haute couture enterprises are carried out unilaterally from the perspective of its development mode, marketing techniques and technology application, while relatively few researches are carried out from the perspective of consumers. Therefore, this paper analyzes from the perspective of consumer demand, which is conducive to providing feasible references for the consumer research of haute couture enterprises.

\section{Analysis on the Development Status of LANYU Enterprise Based on the Perspective of Consumer Demand}

Consumer demand is closely related to haute couture garment enterprises. Consumers' demand for high-end, high-quality and personalized products often dominates the decision-making direction of related enterprises in product research and development, marketing execution and other aspects. At the same time, enterprises in the process of development should pay attention to consumer lifestyle, spiritual pursuit and other aspects of research. Only by creating products that fully meet the needs of consumers can enterprises maximize the love and support of consumers. LANYU company started from a small workshop whose business includes design, production, sales and so on. Its rapidly developped to become a haute couture enterprises, which focus on custom wedding dresses. It insists on providing customized clothing services for high-end consumers who pursue beautiful things and pays attention to the creation of product quality. It also innovated and applied various marketing techniques, formed its own core competitiveness and brand strength, and won great attention in the field of haute couture in China.

\subsection{A Fit between Service Concept and Emotional Needs of High-End Consumers}

When running a business, LANYU aims at high-end consumers, listens to the aspirations of target consumers, understands their appeals, and carries out the concept of "serving customers" to the end. As early as when LANYU started her business, she had set up the awareness of serving consumers with products, had an in-depth understanding of consumers' demands, and formed her own VIP profile. The content of the profile was accurate to consumers' reading preferences, interests and hobbies, etc. The loyal consumers cultivated in the initial stage laid a solid foundation for the later development of the enterprise. When the enterprise grew, LANYU positioned herself and every member of the team as a consumer listener, fully understanding the life stories, dress requirements and real thoughts of high-end consumers. According to her ideas, she inspired the design of high-end gowns, and adjusted the gowns for many times to meet the needs of consumers. In order to cooperate with the work and life of high-end consumers, LANYU also provides door-to-door service, making the service ideal to implement the development of its enterprise. 


\subsection{Creating Products to Meet Material Needs of Loyal Consumers}

Different from most haute couture enterprises, LANYU positioned her products in the most important dress of girls' life at the beginning of her business. It adheres to the design concept of "Just for you, Just for love", and its target consumer group is customers aged between 16 and 35 years old. The exploration of market blank spots has become one of the reasons for its success. The particularity of haute couture enterprises determines the limitations of their target audience. In order to further develop the market and enable loyal followers of the brand to buy the desired products at a lower price, LANYU has opened up the clothing line. In the case that the product image is not damaged, consumers can obtain the largest consumer surplus and maximize the benefits, and win a larger market for the brand. On the product craft, LANYU has explained the real value of haute couture by its specialized manner. Combining traditional Chinese $\mathrm{Su}$ embroidery techniques with advanced western fabrics, and delicately combining soft and modern western designs, LANYU insists on being the carrier of Oriental elegance. In order to create a unique lace material, LANYU set up its own research and development center, opened a customized lace production line, constantly strengthen their brand competitiveness. Product development cost has always been the pain point of the majority of haute couture enterprises, and LANYU has been committed to research how to improve the quality of products in the case of maximum cost control. For example, the lace successfully developed in France and produced in China accelerated the pace of product upgrading.

\subsection{Meeting the Information Acquisition Needs of Popular Consumers}

While focusing on service concept and product creation, LANYU also pays great attention to the application of marketing techniques. LANYU design wedding dress for Luo haiqiong, Xie na, Dong Xuan and other stars that helped to open the wedding dress custom market. The application of "Star effect" carried the first batch of consumers who pursuit popular for company. The red carpet auditorium of the film festival attended by all the stars has also become the haute couture show of LANYU, which has greatly improved the brand awareness and gained the attention of potential consumers. In addition, "cross-border cooperation" is also a marketing strategy commonly used by LANYU. The cross-border fields include automobile, smart phone, film and television works, jewelry brands, beauty makeup brands, concerts and so on. This kind of omni-directional and multi-field cooperative marketing has virtually improved the premium ability of enterprise brands and greatly increased brand attention. At the same time, WeChat conference live broadcast, micro-blog fun sharing, college student speech, meeting and other online and offline multi-channel interactive ways have also made great contributions to the formation of corporate brand loyalty, but also provides more opportunities and possibilities for the consumers who pursuit fashion. 


\section{Discussion on the Development of Chinese Haute Couture Enterprises}

\subsection{Brand Concept and Service Concept Enhance from the Perspective of Consumer Emotional Needs}

The information society makes the way of information dissemination more convenient, and the way consumers obtain information more simple and diversified. In this social development trend, the consumer loyalty of enterprise brand is decreasing. The key for haute couture enterprises to obtain consumer loyalty lies in emotional factors. Therefore, haute couture enterprises should pay attention to observe the emotional needs of consumers and emphasize the concept of serving consumers. In the next few years, the new middle class will become the main force of customized product consumption. It is necessary to fully understand the emotional appeal of target consumers for clothes and provide high-quality products and services in line with market demands. Through various online and offline activities, LANYU has formed multi-party communication with consumers and continuously explored their emotional needs, so as to continuously improve their experience and gain consumer loyalty.

In addition, the consumer stickiness of high-order products largely depends on its service and exclusive characteristics, so it is necessary to be ready to serve consumers at any time. In this process, the service concept and professional quality of practitioners are particularly important. Haute couture enterprises should organize regular training for practitioners, comprehensively improve the service awareness and professional knowledge system of practitioners, so as to fit the lifestyle and emotional needs of target consumers and provide better services for consumers. LANYU has been adhering to emotional marketing, positioning team members as a consumer listener, the dream of the dress, which requires practitioners in the service awareness at the same time have deep clothing related professional knowledge, to provide consumers with better service.

\subsection{Product Upgrade through Intelligent Manufacturing Technologies}

With the development of science and technology, 3D printing, intelligent manufacturing and other technologies are becoming more and more mature. The application of science and technology can reduce complex and unnecessary manual operation links, such as the application of digital technology platform for clothing and the combination of intelligent human platform. Although the introduction of technology will inevitably lead to high production costs, in the long run, partial process replacement reduces many unnecessary expenses. The introduction of intelligent technology also promotes the development of sustainable production and saves a lot of energy. More importantly, the introduction of intelligent manufacturing technology can bring better consumption experience to consumers, improve the functionality of clothing, and make clothes more in line with consumption habits. At present, haute couture enterprises like LANYU 
emphasize more on manual customization, and the popularity of intelligent manufacturing is still low. Chinese haute couture enterprises should form their own high-level language, keep pace with the times, actively embrace digital technology, and inject new vitality into enterprises.

At the same time, the enterprise can set up its own research and development center if conditions permit, and hire professional fabric research and development personnel to take the place of research and development management, saving the cost of fabric procurement at the same time can also improve product design, consolidate brand competitiveness, in order to obtain more consumer recognition. In the beginning, it cooperated with the famous French lace supplier to complete its own design concept. However, the research and development cost was expensive. Based on its long-term development, the company purchased a lace workshop and established its own research and development center to realize product upgrading.

The single one-to-one and multi-pair fixed system acquires all consumer surplus, and it is difficult to open up the market to get more attention from potential consumers. After the success of LANYU brand in haute couture market, its product line was divided into three parts. After the establishment of haute couture brand IN LOVE LAN, it immediately launched light customization series and sub-line clothing brand LAN BY LAN. The price of high-set gowns is relatively expensive, most of which start from 120,000 yuan, while the light customized gowns still use high-grade fabrics but eliminate the complicated craft, with the price ranging from 10,000 yuan to 40,000 yuan, and the clothing series covering from hundreds of yuan to thousands of yuan. The coverage of multiple product lines can obtain more consumer surplus and avoid market risks to a certain extent. This is the practice that each haute couture enterprise can draw lessons from. However, from the point of view of LANYU's ready-to-wear series, the product categories and quantity are relatively small and have not formed a scale, so the enterprise still needs to strengthen the construction of the design team.

\subsection{Brand Awareness Improve by Integrating Multiple Channels}

Due to the late start of haute couture market in China, consumers' cognition level of haute couture is still at a relatively shallow level. Coupled with the limited understanding of domestic haute couture brands, consumers are at a loss in the face of choice. Therefore, the major brands need to integrate the major marketing channels, increase publicity and promotion efforts, to improve brand awareness. LANYU design Wedding dress for a large number of stars and won the first batch of consumer recognition, famous stars obtain the maximum exposure for haute couture. At the same time, LANYU also cooperated with movies and TV series to promote her brand, so as to let the audience understand the brand concept and brand positioning in a more vivid way. In order to attract consumers to a greater extent, the construction of WeChat and Weibo platforms 
as well as the construction of Tmall online stores also played an effective role. Of course, LANYU also regularly holds offline salon activities with various themes to have zero contact with brand supporters, establish a good communication platform, understand customer needs, and absorb new vitality for brand construction.

\section{Conclusion}

The general trend of consumption upgrading is becoming a favorable driving force for the development of quality consumption. From the perspective of consumer demand, the rise of the new middle class will inevitably bring more high-quality, personalized consumer demand, and the development prospect of China's high-end enterprises is considerable. However, there is still a long way to go for Chinese haute couture enterprises to achieve long-term and stable development. The market should be good at learning from the advantages and development strategies of relevant mature enterprises, and achieve greater development by combining its own brand characteristics, so as to jointly push China haute couture to the world fashion stage.

\section{Support}

Project Number: 17JDGLB003.

Project Name: Research on product design and development of Chinese women's wear based on the application of traditional Chinese elements.

Project Source: Beijing social science foundation research base project.

\section{Conflicts of Interest}

The authors declare no conflicts of interest regarding the publication of this paper.

\section{References}

[1] Zhao, Y. (2015) Research on Marketing Strategy of Local Custom Dress Enterprises in China: Taking Lanyu Company as an Example. Ph.D. Dissertation, International Business School, Beijing.

[2] Chen, M.M. (2016) Research on Men's Shirt Customization Mode Based on Customer Experience. Ph.D. Dissertation, Tianjin University of Technology, Tianjing.

[3] Liu, H. (2018) Comparative Study on Women's Brand Marketing Model. Ph.D. Dissertation, Beijing Institute of Fashion Technology, Beijing.

[4] Zhang, X. (2017) Research on the Correlation Design of "Shape" and "Feeling" in Haute Couture Clothing. Ph.D. Dissertation, Zhejiang University of Science and Technology, Zhejiang.

[5] Chen, W.L. (2016) Preliminary Study on Women's VIP Custom Design Management. Ph.D. Dissertation, Beijing Institute of Fashion Technology, Beijing.

[6] Dong, Z.X. and Li, Y.N. (2015) A New Pattern of Emotional Design for Haute Couture. Textile Journals, 12, 152-157.

[7] Peng, H. (2016) Research on the Influence of Customer Perceived Value of Digital 
Intelligent Customization on Brand Loyalty. Ph.D. Dissertation, Zhejiang University of Science and Technology, Zhejiang.

[8] Zhang, B.L. (2017) Research and Implementation of Apparel Advanced Customization Platform Based on C2M Model. Ph.D. Dissertation, Xi'an Engineering University, Xi'an. 